A CRISIS IN THE MIDDLE AGES. 


\section{A CRISIS IN THE MIDDLE AGES.}

By Rev. JAMES CLEMENT MOFFAT, D.D.,

Professor of Church History, Theological Seminary, Princeton, N. J.

Pope Gregory VII. had pronounced excommunication upon Henry IV., Emperor of Germany, and divided the German princes. The latter held a meeting, at which it was resolved that Gregory should be invited to Augsburg to hear, in an assembly of the princes, all the charges against their emperor, after which the final decision of the case should be left to the pope. But if Henry, by any fault of his own, remained under excommunication a year, he should be considered incapable of ruling forever. Meanwhile he was to live in a private capacity.

The emperor did not, by any fault of his own, remain under excommunication, but hastily undertook a fatiguing journey over the Alps, in midwinter, to have the papal infliction removed as soon as convenient, and had sought presentation to his Holiness in a manner alike respectful to the papacy and the empire. Gregory was on his way to Augsburg, and met the emperor at Canossa, a castle in the north of Italy. There, instead of what a proper-minded gentleman would have done even to an enemy captured in war, the pope, in the month of January, compelled his royal applicant to denude himself of his suitable attire, and to stand fasting on the outside of the castle, in the most abject clothing, for three days, before admission was granted him. And, when admitted, it was only to receive a limited absolution, on condition of appearing before the proposed court in Germany, where all the charges against him were to be repeated -a mockery of absolution. It was, however, in the conflicting spirit of the previous time-a time of warfare and of general violence. 
The preceding two hundred years had been, for the greater part, a progressive degeneracy on both sides, high and low, rich and poor. Private wars became so common that people could not go to church without the risk of life involved in the quarrels of one party or another. And some of the highest clergy, especially the popes, were themselves the deepest sunk in guilt. From the latter days of the Carolingian princes, the breaking down of their hereditary empire, and the creation of its electivity, while the popes, elective by a more persistent body of electors, and claiming the superior branch of the monarchy, as that proceeding from on High, and yet deriving it from the most licentious depths of earth, there had been rarely a free monarch or an independent pope. The attempts of civil monarchs to purify the evils complained of in the Church had more effect to promote papal ambition than to restrain the baser desires. Early days of the first Carolingians were hopeful of better times. But the last years of the ninth century settled down on conceited fictions of papal ambition, in the false decretals, and the false donations of Constantine, and expectations to realize the sensual elements to proceed from them. The sequel was that the whole tenth century and, at least, two thirds of the eleventh must be included as, immorally, the darkest depth in the Middle Ages, and the most profligate of what was called the Christian world, while a blind despotism aimed at absolute constraint of government, ordered by men whose orders were passions, and among whom the most abandoned were the popes themselves. To such a degree of revelry was their irregularity often carried that the emperor had sometimes to be invited from Germany to compel the pope in Rome to decency of deportment.

From about the middle of the eleventh century the monk Hildebrand, for twenty years, had done much for good external order. But his plan for effecting good order was to compel, a plan always liable to retaliation. He knew no other means than force. The men of that time had to fight for order, if order was to be obtained. And Hildebrand was a stern adherent to the method of compulsion, obtrusive of 
his own impulses to the last extreme. In his treatment of the Emperor Henry IV., at Canossa, he evinced an amazing oversight of human nature by inflicting what could not be other than a mortal indignity, gratuitously insolent, upon a man accustomed to the highest honors of sovereignty from his youth. But Gregory VII. was still the monk Hildebrand. And in all those three days and nights during which the half-naked emperor stood outside of the castle walls, did the pope take it into his head that the young monarch might retaliate upon him? No; he seems to have been actuated entirely by ideas of the cloister, as if an emperor was to be reduced to obedience like a disorderly monk. It has been boasted as a victory of the pope over the emperor, a strangely obstinate error indulged in by the general public for not less than eight hundred years, to the complete overlooking of the real fact in the case.

That one act of vulgar rudeness proved a fatal mistake for Gregory, personally as well as politically. The emperor had been at the head of successive armies, and might be the leader of others, in spite of all mere verbal conditions. The limited absolution grudgingly yielded to Henry, and meant by the pope to be conclusive in nothing, was enough for the king's subjects in Northern Italy. They, learning that he had received absolution, immediately took it for valid, as it ought to have been, and held him to be restored fully to his power among them. For other reasons of their own the northern Italians had few friends to Gregory among them. Moreover, a strong party in Germany defended the cause of their young monarch. The pope did not cross the Alps. It was too dangerous. The hatred of Gregory among the northern Italians amounted to abhorrence, and Henry, for submitting to the indignity, was coldly received for a season. But that passed over. The court where Gregory was to preside at the trial of an emperor was indefinitely prorogued. The trial resolved itself into a military difference of opinion, which ultimated in defeat of the pope's party; and the emperor's march at the head of his victorious army to Rome, with his own pope to be installed, while Gregory 
took refuge in the Castle of St. Angelo, from which he was rescued by the Normans under Robert Guiscard, and carried to Salerno, where he died, I085.

Such was the often boasted victory of the pope over the emperor. 'It was the very opposite. Henry had, for the time, the decided advantage, and set up and maintained his own pope, or anti-pope, Clement III., in Rome. But the Gregorian party also elected theirs, Victor III., a very reluctant one, who never entered into the spirit of his office, and when he died, the same party elected Urban II., a man who, without violence, knew the path to success.

The policy adopted by Gregory VII. relied upon force, the style of the long preceding time. Urban II. saw that the papacy was not endowed with any real force, and could not hope ever to command the commanders of armies in their way. It was humiliating to sustain a policy pretending force, by having to solicit military aid. Urban II. made no such pretension. His alliance with the Norman Duke of Apulia and Calabria was merely a Christian friendship, in which he might take refuge if violence assailed him. His sacred office he deeply perceived must be sustained by the religion it professed, not by force for the triumph of superior force, but, if by force at all, for the triumph of Christ. And yet there was much difficulty in effecting that end by such means. At the end of seven years from his election, although gradually gaining ground morally, his position was still precarious.

It was then that a pilgrim arrived from the Holy Land destined, without any intention on his part to that end, to effect more to sustain the cause of the desponding pope than could have been done by any prince in Christendom. The pilgrim sought an interview with the homeless pontiff, narrated his adventures and sufterings, made his confession to him, and from him received a full and frank absolution. He also recounted the sufferings which the Oriental Christians had to bear from Saracenic cruelties.

Urban also granted the pilgrim his cordial permission to preach an expedition against the oppressors of the Holy 
Land, which he had been commissioned to solicit by the pontiffs of the East.

Thus vested with all proper authority, the pilgrim issued forth on his memorable mission. It was in the spring-time of the year 1095 when he crossed the Alps into the Northwest. Multitudes of returned pilgrims, with their tales of adventure and of danger, then scattered over Europe, had already aroused the indignation of all classes of people, and prepared them like tinder to be kindled by the fiery eloquence of the new apostle.

But Peter the Hermit was followed by a more powerful spokesman,-not more entertaining, but one who earnestly aimed at conviction of practical truth, and especially in the minds of men who loved the Gospel. Pope Urban II. used the facts of Peter's tales to enliven his argument for the cause of Christ. Peter awakened the popular enthusiasm. Urban organized the whole scheme. He held a numerous. council on the subject at Placentia in March, 1095, and another in November of the same year at Clermont in Auvergne, at both of which he pled with powerful persuasion a war for rescue of the holy places-the places upon which the feet of Christ had trod. Peter was also at Clermont, but Urban alone was prepared with a complete: organization for the enterprise, and proposed the badge of a red cross for all who were willing to enlist in it. But for those organizing means, the excitement created by Peter the Hermit would have been only like fire upon the prairies, sweeping over the country and leaving behind it nothing but the marks of burning.

At Clermont a vast multitude of laity and of clergy assembled in church and in the open air. The very locality was exciting, commemorative as it was of the heroic days of Auvergne. The lofty Puy-de-dome lifting his head and shoulders above all the other mountains, looked down upon the old historic scene as in the days of Cæsar and of Vercingetorix. It was impossible that the Auvergnese should not have been moved to an enthusiastic zeal. The arguments of Urban were responded to by the unanimous shout, "It is. 
the will of God!" "Deus lo volt!" shouted the unlearned. "Deus vult!" said the clergy. The bishops separated to preach the crusade to their respective people. Urban himself spent many months to the north of the Alps, employing himself in the spiritual interest of the Church. Hundreds of thousands of the laity assumed the red cross, and some in their zeal branded the eross upon their own bodies and enlisted in the expedition. From Urban every thing proceeded in the name of Christ and association with Christ and the cross, and to facilitate the distribution of the latter, the business it involved was assigned to Ademar, the Bishop of Puy, who was to see to the central duties in Auvergne.

Without counting the disorderly rabble who followed Peter the Hermit, as many as six hundred thousand trained men followed Godfrey of Bouillon, Robert of Normandy, Robert of Flanders, Tancred of Sicily, Raymond of Toulouse, and others, with an ardor and power which proved irresistible. Although a brave defence was encountered at Nice, at Antioch, at Edessa, and elsewhere, the vast army of zealous crusaders, in the spirit of their shout at Clermont, "It is the will of God!" on the I $5^{\text {th }}$ of July, Iog9, entered Jerusalem in victory. The triumph of Urban was complete. He was lifted above all mere human rivalry. The population of western Christendom had sustained him as the advocate of Christ. Their volunteer ranks had laid the Greek empire and Oriental Christians under a solemn obligation before Christ. They had subdued the Sultan of Roum, had removed the anti-Christian opposition which had encountered them in Syria, and rescued Jerusalem and the sepulchre of Christ, with the Holy Land, from the abuse of heresy and the false prophet.

That, in its way, was a real Christian revival over against Mohammedanism, and the thousands who returned from the crusade returned with greater interest in the cause of Christ.

Fourteen days later Pope Urban II. died-too soon for him to know the depth and breadth of the influence he had wrought, or the nature of which it was. But he had left the Christian world in a better frame of mind, a more direct and practical Christian zeal. 
The next two hundred years were of a different spirit from the preceding two hundred, almost entirely.

The tenth and eleventh centuries, with their shameless immoralities, were never brought back to the Christian world again. New days dawned in brighter hopes. The beautiful meditations of Anselm had already begun to ascend above the horizon. And soon afterward arose the greater orb of Bernard, followed by the school of William of Champeaux, and the greatest among teachers, the brilliant Abelard. Intellectual pursuits increased, learned scholastics sought deeper fountains of truth; to them we are indebted for the first complete treatment of theology scientifically. I do not mean philosophically, for we had that long before from Augustine. Their reputations crowded their schools with pupils. Christian society was supplied with theology, with philosophy, with devotional treatises, poetry of popular songs, the work of troubadours-very far from being all unsanctified,- -hymns of the Latin hymnolgists-of which we are only beginning to discover the value. The pious singers of those two hundred years ceased not successively to fill their places of charming song, until the morning of the fourteenth century rose upon the world, and Dante, rejoicing in its light, gave forth the harmonies of his Divine Com thedia.

The fourteenth century never surrendered her intellectual gains. Improving reformation declared itself as time went on. And material nature added her discoveries to the labors of human intellect. And, notwithstanding the adversities of the fifteenth century, the Christian depth and truth of devotion which spread abroad in the worship of the Mystics, supplied the sincerest devotional part of the Reformation.

The most valuable literature of the Middle Ages was produced between the beginning of the twelfth century and the end of the thirteenth. It was the period of the greatest scholastics. It was that which created the universities. It laid the foundations of our scientific theology, and created our science of the material world and our modern systems of education. 